\title{
SUSTAINABLE LANDFILL FINE FRACTION OF WASTE REUSE OPPORTUNITIES IN COVERING LAYER DEVELOPMENT
}

\author{
*Juris Burlakovs ${ }^{1}$, Jovita Pilecka ${ }^{2}$, Inga Grinfelde ${ }^{2}$, Lauris Arbidans ${ }^{1}$, Dace Arina ${ }^{3}$, Roy Hendroko \\ Setyobudi ${ }^{4}$ \\ ${ }^{1}$ University of Latvia, Latvia \\ ${ }^{2}$ Latvia University of Life Sciences and Technologies, Latvia \\ ${ }^{3}$ Institute of Physical Energetics, Latvia \\ ${ }^{4}$ Waste Laboratory, University of Muhammadiyah Malang, Indonesia \\ *Corresponding author's email: juris@geo-it.lv
}

\begin{abstract}
Resources are lost in dumps from the time civilization knows itself. Solid waste handling through 'zero waste' concept is important for disposed waste reuse/recycling. The challenge for future is landfill mining (LFM) - one of the approaches dealing with that approach. We can think of recycling of valuable components such as plastic, metals and even rare soil elements if we have the right technology. Fine fraction of waste derived from excavated, separated and screened waste is also a perspective of circular economy as this inert fraction may serve as methane degradation layer for covering the old as well as new landfills. It may reduce harmful $\mathrm{CH}_{4}$ emissions and diminish the raw material use for closure of dumping sites. The aim of this study is to give an outlook on opportunities and describe other benefits for circular economy from innovative construction technology of cover layer.

Rejected material may contain up to $40-60 \%$ of dump site/landfill mass and we may have interest in: 1) estimation of fine fraction of waste as functional construction material; 2) watching environmental effects - possible leaching and emissions; 3 ) keeping dumpsite revitalization as the master plan idea. First studies revealed the potential of fine fraction of dumpsite material for sustainable covering layer development. This study is supported by the project No.1.1.1.2/VIAA/3/19/531 'Innovative technologies for stabilization of landfills - diminishing environmental impact and resources potential in frames of circular economy'.
\end{abstract}

Key words: landfill biocover, fine fraction of solid waste, circular economy, landfill revitalization.

\section{Introduction}

Landfills and environmental concerns have been studied widely (Burlakovs et al., 2013; Critto et al., 2006; Prokop, Schamann, \& Edelgaard, 2000). Studies about monitoring, leachate, opportunities of recycling, etc. are of critical importance (Burlakovs, Kasparinskis, \& Klavins, 2012). Innovative technologies of research and applied action are needed to break the vicious cycle of burying the waste without interest on reuse/recycle of valuables as well as diminishing landfill gas emissions (Burlakovs et al., 2014, 2017, 2019).

In the context of landfill mining prospection and exploration, activities are performed to locate landfills, estimate their dimensions and characterise the material quantities and qualities. In this way, data for a feasibility study are obtained. The importance of proper exploration in the early stages of a possible landfill mining project has been highlighted by Hull et al. (2005), Goeschl (2010) and Burlakovs et al. (2015).

The aim of this study is to give an outlook on opportunities and describe other benefits for circular economy from innovative construction technology of cover layer. Landfills pose serious environmental threats if not closed and revitalized property; moreover, we have to deal with harmful greenhouse gasses such as methane (Burlakovs 2008, 2012; Ozola et al., 2019; Pehme et al., 2020). Innovative solutions for hydrological imrovements and diminishing of leachate contaminants, including nutrients and dissolved organics are of high importance (Tamm et al., 2008; Saaremäe et al., 2014; Pehme et al., 2019).

The problematics of the process also includes the necessity of revitalization of the dump site so the site in some occasions may be useful as the industrial, commercial or even green area after the completion of remediation (Hogland et al., 2018; Pehme et al., 2018; Valujeva et al., 2018).

Sampling and sensing aim at producing a model of the reality. Techniques which can support this process are image processing methods, geostatistical modelling and prediction, reconstruction of stratigraphy and layered build-up. The material characterisation is crucial, yet still in a very early stage of development. The combination of several sensing techniques should offer a potential to solve this process (Burlakovs, Kriipsalu et al., 2013). The quality of LFM material determines the recycling opportunities and the choice of a processing technology. The combination of these methods can also be used for the products of valorisation technologies to quantify the value added due to processing (Burlakovs et.al., 2016).

For ex-situ LFM, there are a number of separation challenges which are not as significant in typical waste processing set-ups. The high proportion of soil material means that a relatively low percentage (compared to untreated household waste) of the excavated material is available for recycling or energy recovery. Quaghebeur et al. (2013) reported that almost 50\% 
of excavated waste was soil-like material. In other LFM projects this number is even higher, in Maul et al. (2014) found that up to $70 \%$ is fine fraction $(<60$ $\mathrm{mm}$ ). The machinery in sorting plants is applicable for LFM, but the fine fraction treatment part of the plant will face overloading issues. When considering the feeding of these kinds of plants with a screw feeding device, the high amount of soil-like fines will lead to technical problems. The feeder will face clogging issues and therefore a steady-going feeding is difficult to accomplish. As suggested by Quaghebeur et al. (2013), when the organic components are removed, the remaining material might be recycled as filler in concrete or other construction materials (e.g. in mortars if particle size is below $2 \mathrm{~mm}$ ). However, the quality of the soil-type waste may not always be suitable for recovery because of elevated metal concentration $(\mathrm{Cd}$, $\mathrm{Cr}, \mathrm{Cu}, \mathrm{Ni}, \mathrm{Pb}$ and $\mathrm{Zn}$ ), especially in the fine fraction of inert waste. This last type of waste should preferably be reused in different products and one of them is the functional construction material as the covering layer for the closure of the landfills.

\section{Materials and Methods}

The excavation and separation techniques in landfill mining

Excavation techniques, both continuous and discontinuous systems, in landfill mining can be similar to those applied in surface mining. Site location, landfill volume and geometry, physical and chemical properties of waste materials and their spatial location will affect the applicability of the adequate mining method and system. Geometrical characteristics can define the sequence of mining, in strips, terraces or in a traditional cone-shaped excavation. The excavation geometry or layout has to consider the accommodation of the main equipment and their operations, namely benches, haul roads, overburden and waste disposal sites. Other aspects like transport distances and environmental restrictions (Geysen, 2013) will also influence the methodology.

The removal of waste material from a disposal site may require the use of heavy mining equipment. This equipment is the same type of equipment that might be seen at road building projects, including backhoes, bulldozers, and front loaders (Burlakovs \& Vircavs, 2011; Jain et al., 2014). Excavation and especially waste transport create traffic, which, consequently, creates emissions such as e.g. dust in dry climate conditions. On certain sites, custom-designed equipment may be used to prevent the spread of contaminated waste and protect the health of workers and nearby populations.

Excavation using other mixed or continuous systems can minimize or eliminate $\mathrm{CO}_{2}$ emissions, dust, noise and vibrations due to the replacement of diesel engines of heavy machines by electric equipment (continuous mechanical excavators, road headers, draglines, bucket wheel excavators, scrapers and belt conveyors). These systems, when properly designed and adapted to landfill mining, can have some environmental advantages to the operation of excavation. Continuous excavator machines are mobile and perform several operations at a time: excavation, loading and transport to other devices like belt conveyors and can be remotely controlled (Figure 1).

The usage of excavators to remove waste material and/or final and intermediate cover layers from the landfill body is a commonly applied method in the landfill mining context. In general, there are two methods (Figure 2) for excavating landfills (Goeschl, 2010):

- Excavating from the top of the landfill with an excavator in approx. 3 meter levels;

- Excavating from the bottom with a front loader beginning with the removal of thinner layers.

In practice, excavating from the top has been found to be the most effective and economical method.

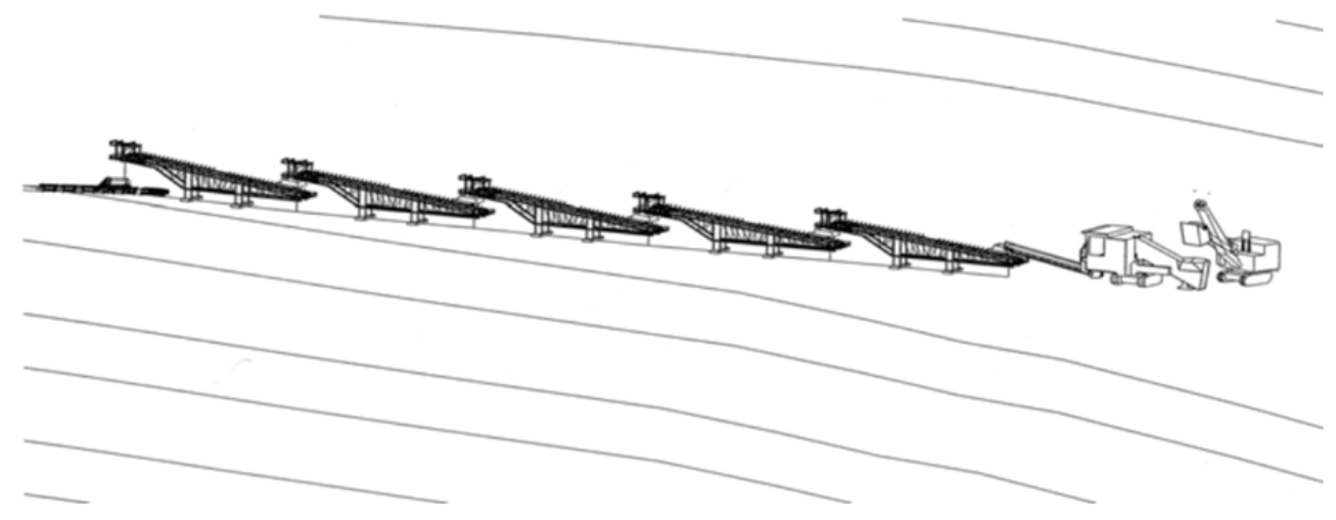

Figure 1. Schematic view of continuous mining equipment. 


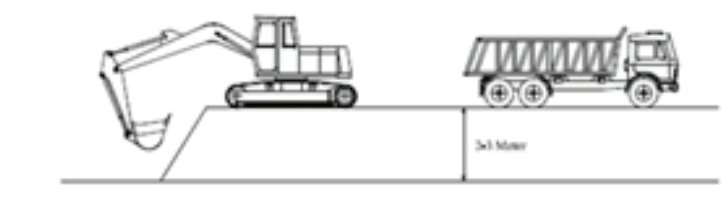

a $\rightarrow$ Direction of digging

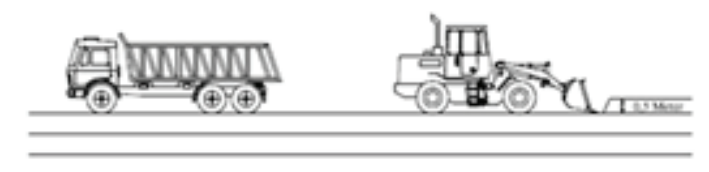

$\mathrm{b}$ $\rightarrow$ Direction of digging

Figure 2. Landfill excavation methods: ${ }^{\text {a }}$ - digging below ground level;

b - digging layer by layer (Goeschl, 2010).

When excavating from the top of a landfill in layers, a typical depth for each layer is 2 to 3 metres. The daily volume of excavated waste is usually limited by factors other than the excavator, such as the capacity of the treatment plant. One example of excavated volume from a landfill in the United Arab Emirates showed an average of $1200 \mathrm{~m}^{3}$ waste excavated per each excavator (Goeschl, 2010). In the most typical case, the excavator equipment stands on top of the landfill and moves backwards while excavating. The front loader with thinner layers has been advised to be used mostly for cleaning of the natural soil on landfill bottom layers and in special cases. The cover layer of the landfills is often kept separated from the excavated waste (Jain et al., 2013).

Other excavation methodologies, especially those that use continuous systems, should be encouraged since they have proven their efficacy in mining and construction activities. On the one hand, they allow geotechnical impact mitigation, since the equipment is outside the landfill and far from slopes during excavation. On the other hand, these continuous excavation systems assure vibration absence and eliminate the dangerous weight effect near the slopes. Leachate, Dust and Environmental Safety

Landfill leachate has been studied in many types of landfills such as municipal solid waste (MSW) (Di Bella et al., 2012), steel slags (Gomes \& Ascenço, 2006) and polymetallic sulphide mining wastes (Kontopoulos et al., 1998; Cosme \& Gomes, 2004). In these studies, leachate quantity and quality was assessed during different periods of time (Münnich, Bauer, \& Frickle, 2012) and experimental works were carried out in order to prevent and mitigate leaching. Besides the traditionally known environmental problems derived from leachate, the nature of landfill materials may also be a concern. Some landfill mining activities such as waste handling, storage, and plant traffic have great potential to produce coarse and fine dust particles that can be harmful for public health. Moreover, depending on waste nature, particulates emitted from landfills may also contain metals such as arsenic, cadmium, chromium, cobalt, copper, lead and manganese. For these reasons, landfill sites require dust monitoring, controlling and suppression measures to avoid substantial environmental impacts. For many decades dust has been studied as an environmental impact factor by several authors. In the latest years, as a consequence of technological development, the harmful effects of ultrafine particles and nanoparticles on public health have been subject to intensive research. One example is the work published by Gomes et al. (2013), where a methodology for monitoring ultrafine particles/nanoparticles in varying environments was evaluated. This approach utilizes online analysers and sampling systems which allow further characterization on collected nanoparticles.

\section{Results and Discussions}

Energy issues and functional covering material from fine fraction of waste

Apart from natural and expected variations, it is obvious that inorganic (inert / fine fraction) components always represent a significant portion $(>50 \mathrm{wt} \%$ ) of the mixture. They are formed by the soil fraction used as intermediate/final covers of the landfill and by the inorganic components of the wastes (e.g. from C\&D or industrial sludge, etc.). Since Waste-to-Energy (WtE) operations have a crucial role in landfill mining (Bosmans et al., 2013), as a viable alternative to process organic components in the mixture, fine ashes and/or slags are expected to be formed, according to the used combustion technology (Themelis, 2007).

Inorganics tend to be concentrated in the fine fraction (<10 $\mathrm{mm}$ sieve) but coarser particles (e.g. aggregates) are also present (Hogland, 2002; Quaghebeur et al., 2013; Kaartinen et al., 2013). Finding valorisation opportunities for these materials is a challenge, due to their compositional variability and presence of certain undesirable constituents (e.g. chlorides). Most of those components are inert or non-hazardous according to the EN 12457-4 standard (Hogland, 2002; Kaartinen et al., 2013). However, their potential valorisation requires a careful look at the major elements and at certain specific (problematic) constituents, such as chlorides and heavy metals.

In the context of landfill mining or resource recovery from waste, the concept of land asset recovery is not something that contributes to the 
application of the technology per se; in fact it is the other way round as the method of resource recovery may impinge upon future use of the land. The design of the waste mining process may take account of this in order to maximise future benefits, as it is this that will govern the site behaviour and condition following processing. The potential for landfill mining is high for developing the covering material / capping to: 1) restore the land; 2) reuse/recycle what possible; 3) real estate aspect use as the benefit.

The purpose of land asset recovery is to ensure that the land itself can be reused in a safe and effective manner, generating revenue where relevant and thus maximising the chance that it can return to productive or beneficial use. It has been noted that landfill redevelopment projects may only be feasible financially if government subsidies are provided (Roccaro, 2013). In such cases, the inclusion of waste mining and resource recovery may increase financial returns and make such redevelopment financially more attractive.

Potential of methane oxidation in covering layer of landfills depends on various factors often studied in applied ongoing closure projects (Pehme et al., 2020). There are still difficulties with quantifying landfill fugitive methane emissions due to the high temporal variability and spatial heterogeneity of emissions. Cost-effective methods for measurements of landfill methane is a challenge to the scientific community.

Examples of low intensity use or light structures are relatively widespread. In particular, the creation of amenity sites such as parkland or sports facilities is well established. A range of examples are provided by the USEPA (1999), including sports pitches and golf courses. Chemlal et al. (2013) report a park constructed on a former landfill which required continued groundwater treatment following construction. Ecological restoration is also often considered to be relatively easily constructed, and it is self-maintaining. This is particularly the case if the site is relatively remote from further development and such intensive site use would be inappropriate (USEPA, 1999), but the potential to combine this with recreational use and offer of habitat creation and green space in more urban areas has also been considered. Low maintenance sites such as prairies or grassland are considered (Biederman \& Whisenant, 2009) and also have the benefit that they may require relatively little water input, limiting potential water ingress to the waste. Alternatively, there are case studies exploring the potential benefits and problems of greening landfill caps with larger plants such as certain tree species (Hutchings et al., 2001), who found that growth of these more deep-rooted species is perfectly possible if the cap itself is properly designed and constructed to prevent root ingress to the waste. Furthermore, agricultural uses such as crop growth (Spreull \& Cullum, 1987) or cultivation of short-rotation forestry for biofuel generation (Page et al., 2014) have also been considered, but there is relatively little published information available on the success or otherwise of these options.

Creation of structures on closed waste sites is relatively rare due to the long-term issues described above, and because invasive procedures that breach the landfill cap are not desirable. Where they are developed, structures tend to apply relatively little additional loading. Ball, Hill \& Morgan (2006) report the development on existing landfills around Northampton, the UK. These old, unlined facilities contain MSW and potentially hazardous materials that are decades old, with inert and construction waste disposed of prior to closure in the 1990s. The redevelopment reported in this study was primarily concerned with lightweight construction and facilities that were relatively unaffected by settlement. Although the waste was old and it was considered that a significant proportion of settlement had already occurred, site uses comprise surface or low rise structures including car parks for adjacent sports stadia and a recycling centre. Wong et al. (2013) report settlement monitoring of light redevelopment on landfills in Hong Kong - even the use as a park and recreational area was seen to significantly increase settlement rates. Recently, the possibility of constructing solar energy generation systems on closed waste sites was explored by Sampson (2009). The existence of open space with less likelihood of site development and shadowing from nearby constructions makes such sites particularly suitable. As with any construction, however, the potential for differential settlement exists, which in this case could detrimentally affect foundations and electrical connections as well as cap integrity. Also, solar panels constructed on the slopes of land-raise waste facilities may exacerbate slip failure mechanisms.

Invasive redevelopment of landfill sites offers similar issues to those raised by landfill mining, including health and safety concerns during the process but also the potential for reuse of the materials. Examples of redevelopment in this way are quite rare, but generally take place on waste sites containing relatively inert materials.

Excavated materials are segregated on site, with suitable uncontaminated fill being reused onsite and the remainder taken to another landfill. Information on how the site will be prepared for construction is limited, but as the majority of biodegradable and contaminated material is removed, it is likely to encompass standard ground improvement techniques.

Although waste disposed of in modern facilities is compacted, subsequent changes in the medium to long 
term mean that the site will be unsuitable for reuse without some form of treatment. For construction, it would be necessary either to remove the waste entirely, design foundations that avoid using wastes as load-bearing materials (e.g. piled foundations) or invoke some form of treatment process. Any treatment process is likely to require removal of the majority of biodegradable material to ensure that further significant decomposition and settlement are avoided. Mining of waste repositories, particularly ex situ, allows this to take place. Remaining inert materials will require ground improvement to provide suitable foundation for future use. Relevant technologies that are already well-established are discussed in some detail by Summersgill and Witherington (2008). Cover systems (i.e. capping) are a straightforward method of protecting against contamination pathways to receptors at the ground surface, similar to a landfill cap itself and with similar elements. Our proposal is to construct the functional material that will diminish the leachate contamination as well as degrade greenhouse gas.

The cover system method is useful with large areas of contamination, which it can treat with the minimum of intervention. Capping does not treat contamination - it remains on site with the potential to cause future harm. This technique is not contaminant-specific as it is simply an inert/ mixed with some organics barrier. However, there may be concern where volatile contamination is present, unless a low permeability cover is used. If there is the possibility of risk from below-ground transport of contamination, then other techniques should be considered, either instead of or in conjunction with a cover that is used from the landfill inert material per sei.

\section{Conclusions}

The landfill closure process is not innovative when state-of-the-art is applied; however, novelty might be found out when landfill mining is proposed with inert material redevelopment as the functional covering material. It provides opportunity to reduce the raw material used conventionally as well as reduce greenhouse gasses while destroying them. Pollutant geochemistry and applied engineering are the key spheres when decision to develop such covering material appears. Innovative closure of landfills by capping with fine fraction of waste mixed with distoinct amount of soil organics is the future of many revitalization projects. Research is continued and overall guidelines of applied approach are dependent not only on scientific approach but also on site geography and legislative aspects.

\section{Acknowledgements}

This study was supported by European Regional Development Fund: project 1.1.1.2/VIAA/3/19/531 'Innovative technologies for stabilization of landfills diminishing of environmental impact and resources potential in frames of circular economy' (literature review, structuring, conceptualization of field experience) and 1.1.1.2/VIAA/1/16/221 'Research of optical and energetic properties of mixed municipal solid waste material for its preparation for a recovery' (visualisation, editing, supervising).

\section{References}

Ball, S., Hill, E., \& Morgan, H. (2006). Sixfields, Harvey Reeves Road and Ransome Road landfill sites redevelopment. In $10^{\text {th }}$ International Association of Engineering Geology and the Environment International Congress Proceedings IAEG2006, paper 405 (pp. 1-14). Nottingham, UK.

Biederman, L.A., \& Whisenant, S.W. (2009). Organic amendments direct grass population dynamics in a landfill prairie restoration. Ecological Eng., 35(5), 678-686. DOI: 10.1016/j.ecoleng.2008.10.016.

Bosmans, A., Vanderreydt, I., Geysen, D., \& Helsen, L. (2013). The crucial role of Waste-to-Energy technologies in enhanced landfill mining: a technology review. Journal of Cleaner Production, 55, 10-23. DOI: 10.1016/j.jclepro.2012.05.032.

Burlakovs, J. (2008). Groundwater sampling for monitoring purposes: Case studies in Latvia. In $8^{\text {th }}$ International Multidisciplinary Scientific GeoConference SGEM 2008. Proceedings Vol. 1. Proc. International Multidisciplinary Scientific GeoConference SGEM 2008 (pp. 687-690). Retrieved March 4, 2021, from https://www.sgem.org/sgemlib/spip.php?article1179.

Burlakovs, J. (2012). Dumps in Latvia: Preliminary research and remediation. In $12^{\text {th }}$ International Multidisciplinary Scientific GeoConference SGEM 2012. Vol. 2. Proc. International Multidisciplinary Scientific GeoConference SGEM 2012 (pp. 55-62). DOI: 10.5593/SGEM2012/S02.V2008.

Burlakovs, J., Janovskis, R., Stankevica, K., Hassan, I., \& Lacis, S. (2014). Removal of heavy metals from contaminated soils by electrokinetic remediation. Research for Rural Development, 2, 122-126.

Burlakovs, J., Kaczala, F., Orupõld, K., Bhatnagar, A., Vincevica-Gaile, Z., Rudovica, V., Kriipsalu, M., Hogland, M., Stapkevica, M., Hogland, W., \& Klavins, M. (2015). Field-portable X-ray fluorescence spectrometry as rapid measurement tool for landfill mining operations: Comparison of field data vs. laboratory analysis. International Journal of Environmental Analytical Chemistry, 95(7), 609-617. DOI: 10.1080/03067319.2015.1036865. 
Burlakovs, J., Kaczala, F., Stapkevica, M., Rudovica, V., Orupõld, K., Vincevica-Gaile, Z., Bhatnagar, A., Kriipsalu, M., Hogland, M., Hogland, W., \& Klavins, M. (2016). Mobility of metals and valorization of sorted fine fraction of waste after landfill excavation. Waste \& Biomass Valorization, 7, 593-602. DOI: 10.1007/s12649-016-9478-4.

Burlakovs, J., Kasparinskis, R., \& Klavins, M. (2012). Leaching of contamination from stabilization/ solidification remediated soils of different texture. Environmental \& Climate Technologies, 9 (1), 12-16. DOI: 10.2478/v10145-012-0011-0.

Burlakovs, J., Klavins, M., Osinska, L., \& Purmalis, O. (2013). The impact of humic substances as remediation agents to the speciation forms of metals in soil. APCBEE Procedia, 5, 192-196. DOI: 10.1016/j. apcbee.2013.05.034.

Burlakovs, J., Kriipsalu, M., Arina, D., Kaczala, F., Shmarin, S., Denafas, G., \& Hogland, W. (2013). Former dump sites and the landfill mining perspectives in Baltic countries and Sweden: GeoConference on Science and Technologies In Geology, Exploration and Mining, SGEM2013. Vol. 1. Proc. International Multidisciplinary Scientific GeoConference SGEM 2013 (pp. 485-492).

Burlakovs, J., Kriipsalu, M., Klavins, M., Bhatnagar, A., Vincevica-Gaile, Z., Stenis, J., Jani, Y., Mykhaylenko, V., Denafas, G., Turkadze, T., Hogland, M., Rudovica, V., Kaczala, F., Møller Rosendal, R., \& Hogland, W. (2017). Paradigms on landfill mining: from dump site scavenging to ecosystem services revitalization. Resources, Conservation \& Recycling, 123, 73-84. DOI: 10.1016/j.resconrec.2016.07.007.

Burlakovs, J., Kriipsalu, M., Porshnov, D., Jani, Y., Ozols, V., Pehme, K.-M., Rudovica, V., Grinfelde, I., Pilecka, J., Vincevica-Gaile, Z., Turkadze, T., Hogland, W., \& Klavins, M. (2019). Gateway of Landfilled Plastic Waste Towards Circular Economy in Europe. Separations, 6(2), 25, 1-8. DOI: 10.3390/separations6020025.

Burlakovs, J., \& Vircavs, M. (2011). Possible applications of soil remediation technologies in Latvia. Environmental \& Climate Technologies, 13 (7), 46-53. DOI: 10.2478/v10145-011-0027-x.

Chemlal, R., Abdi, N., Drouiche, N., Lounici, H., Pauss, A., \& Mameri, N. (2013). Rehabilitation of Oued Smar landfill into a recreation park: Treatment of the contaminated waters. Ecological Eng. 51, 244-248. DOI: 10.1016/j.ecoleng.2012.12.019.

Cosme, N., \& Gomes, J.F.P. (2005). A case study for the prevention of pollutant migration in pyrite cinders deposits. In European Summer School on Innovative Approaches to the Bioremediation of Contaminated Sites Proceedings (p. 400). Bologna, Italy: ISBN 88-88214-33-X.

Critto, A., Cantarella, L., Carlon, C., Giove, S., Petrzzelli, G., \& Marcomini, A. (2006). Decision SupportOriented Selection of Remediation Technologies to Rehabilitate Contaminated Sites. Integrated Environmental Assessment and Management, 2 (3), 273-285. DOI: 10.1897/1551-3793.

Di Bella, G., Di Trapani, D., Mannina, G., \& Viviani, G. (2012). Modeling of perched leachate zone formation in municipal solid waste landfills. Waste Management, 32(3), 456-462. DOI: 10.1016/j.wasman.2011.10.025.

Geysen, D. (2013). Implementation of Temporary Storage at the Remo Landfill Site. In $2^{\text {nd }}$ International Academic Symposium on Enhanced Landfill Mining Proceedings, 14-16 October 2013 (pp. 1-17). Houthalen-Helchteren, Belgium.

Goeschl, R. (2010). System, technology and experience of $17 \mathrm{Mt}$ of landfill mining projects. In $2^{\text {nd }}$ Global Landfill Mining Conference and Exhibition Proceedings, 13 September 2010 (pp. 5.1-5.10). PRo Publications International Ltd 2010, Surrey, UK. Retrieved February 20, 2021, from http://www.propubs.com/images/ stories/documents/glm/LandfillMiningConferenceProceedings2010.pdf.

Gomes, J.F.P., Albuquerque, P., Esteves, H., \& Carvalho, P. (2013). Notice on a methodology for characterizing emissions of ultrafine particles/nanoparticles in microenvironments. Energy and Emission Control Technologies, 1, 15-27. DOI: 10.2147/EECT.S48148.

Gomes, J.F.P., \& Ascenço, C.G. (2006). Leaching of heavy metals from steelmaking slags. Revista de Metalurgia, 42(6), 409-416. DOI: 10.3989/revmetalm.2006.v42.i6.39.

Hogland, W. (2002). Remediation of an old landsfill site. Environmental Science and Pollution Research, 9(1), 49-54. DOI: 10.1007/BF02987426.

Hogland, M., Arina, D., Kriipsalu, M., Jani, Y., Kaczala, F., Salomão, A.L., Orupõld, K., Pehme, K.M., Rudovica, V., Denafas, G., Burlakovs, J., Vincevica-Gaile, Z., \& Hogland, W. (2018). Remarks on four novel landfill mining case studies in Estonia and Sweden. Journal of Material Cycles \& Waste Management, 20 (2), 1355-1363. DOI: 10.1007/s10163-017-0683-4.

Hull, R.M., Krogmann, U., \& Strom, P.F. (2005). Composition and characteristics of excavated materials from a New Jersey landfill. Journal of Environmental Engineering, 131(3), 478-490. DOI: 10.1061/(ASCE)07339372(2005)131:3(478) 
Hutchings, T.R., Moffat, A.J., \& Kemp, R.A. (2001). Effects of rooting and tree growth of selected woodland species on cap integrity in a mineral capped landfill site. Waste Manage. Res. 19(3), 194-200. DOI: 10.1177/0734242X0101900302.

Jain, P., Powell J., Smith J.L., Townsend T.G., \& Tolaymat, T. (2014). Life-Cycle Inventory and Impact Evaluation of Mining Municipal Solid Waste Landfills. Environ.Sci.Technol., 48(5), 2920-2927 DOI: 10.1021/es404382s.

Jain, P., Townsend, T.G., \& Johnson, P. (2013). Case study of landfill reclamation at a Florida landfill site, Waste Management, 33(1), 109-116. DOI: 10.1016/j.wasman.2012.09.011.

Kaartinen, T., Sormunen, K., \& Rintala, J. (2013). Case study on sampling, processing and characterization of landfilled municipal solid waste in the view of landfill mining. Journal of Cleaner Production, 55, 56-66. DOI: 10.1016/j.jclepro.2013.02.036.

Kontopoulos, A.I., Xenidis, A., Papassiopi, N., Ullu, F., Cambridge, M., Gomes, J.F.P., Sousa, R.P., \& Adam, K. (1998). Innovative Industrial Technologies for the Rehabilitation of Land Contaminated from Polymetallic Sulphide Mining and Processing Operations (ROLCOSMOS). In Eurothen'98 Proceedings 1998 (pp. 245274). Athens, Greece, Ref: EUR18310.

Maul, A., Feil, A., \& Pretz, T. (2014). Pre-conditioning of old-landfilled material for further upscale processes. In $2^{\text {nd }}$ Symposium on Urban Mining Proceedings SUM 2014, 19-21 May 2014, Vol. 2 (pp. 1-8). Bergamo, Italy: CISA Publisher.

Münnich, K., Bauer, J., \& Frickle, K. (2012). Long term monitoring of leachate flux into drainage pipes of MSW landfills. Waste Manag Res., 30(1), 49-55. DOI: 10.1177/0734242X10386639.

Ozola, R., Krauklis, A., Burlakovs, J., Klavins, M., Vincevica-Gaile, Z., \& Hogland, W. (2019). SurfactantModified Clay Sorbents for the Removal of p-nitrophenol. Clays and Clay Minerals, 67 (2), $132-142$. DOI: $10.1007 / \mathrm{s} 42860-019-00015-2$.

Page, K., Harbottle, M.J., Cleall, P.J., \& Hutchings, T.R. (2014). Heavy metal leaching and environmental risk from the use of compost-like output as an energy crop growth substrate. Sci. Tot. Env., 487, 260-271. DOI: 10.1016/j.scitotenv.2014.04.021.

Pehme, K.-M., Burlakovs, J., Kriipsalu, M., Pilecka, J., Grinfelde, I., Tamm, T., Jani, Y., \& Hogland, W. (2019). Urban hydrology research fundamentals for waste management practices. In Annual $25^{\text {th }}$ International Scientific Conference 'Research for Rural Development-2019' Proceedings, 15-17 May 2019, Vol. 1 (pp. 160-167). Jelgava, Latvia: Latvia University of Life Sciences and Technologies. DOI: 10.22616/ rrd.25.2019.024.

Pehme, K.-M., Jäärats, A., Orupõld, K., Kriipsalu, M., \& Tamm, T. (2018). Community forestry on remediated landfill site. In $18^{\text {th }}$ International Multidisciplinary Scientific Conference on Earth \& GeoSciences SGEM 2018 Proceedings, 02-08 July 2018 (pp. 203-210). Albena, Bulgaria: International Multidisciplinary Scientific GeoConference-SGEM. DOI: 10.5593/sgem2018/5.2/S20.027.

Pehme, K.-M., Orupõld, K., Kuusemets, V., Tamm, O., Jani, Y., Tamm, T., \& Kriipsalu, M. (2020). Field Study on the Efficiency of a Methane Degradation Layer Composed of Fine Fraction Soil from Landfill Mining. Sustainability, 12(15), 6209, 1-16. DOI: 10.3390/su12156209.

Prokop, G., Schamann, M., \& Edelgaard, I. (2000). Management of contaminated sites in Western Europe. Topic Report. No 13/1999. European Environment Agency, Copenhagen.

Quaghebeur, M., Laenen, B., Geysen, D., Nielsen, P., Pontikes, Y., Van Gerven, T., \& Spooren, J. (2013). Characterization of landfilled materials: screening of the enhanced landfill mining potential. Journal of Cleaner Production, 55, 72-83. DOI: 10.1016/j.jclepro.2012.06.012.

Roccaro, P., \& Vagliasindi, F.G.A. (2013). Sustainable remediation of a closed solid waste landfill site: development and application of a holistic approach. Chem. Eng. Transact., 35, 217-222. DOI: 10.3303/ CET1335036.

Saaremäe, E., Liira, M., Poolakese, M., \& Tamm, T. (2014). Removing phosphorus with Ca-Fe oxide granules - a possible wetlands filter material. Hydrology Research, 45(3), 368-378. DOI: 10.2166/ nh.2013.101.

Sampson, G. (2009). Solar Power Installations on Closed Landfills: Technical and Regulatory Considerations. Prepared for USEPA, Retrieved March 4, 2021, from www.clu-in.org.

Spreull, W.J., \& Cullum, S. (1987). Landfill gas venting for agricultural restoration. Waste Manage. Res., 5(1), 1-12. DOI: $10.1016 / 0734-242 X(87) 90030-9$.

Summersgill, I.M., \& Witherington, P.J. (2008). Remedial Engineering for Closed Landfill Redevelopment in the UK. In International Waste Working Group Conference Proceedings, Crete. 
Tamm, T., Nõges, T., Järvet, A., \& Bouraoui, F. (2008). Contributions of DOC from surface and groundflow into Lake Võrtsjärv (Estonia). Hydrobiologia, 599(1), 213-220. DOI: 10.1007/978-1-4020-8379-2_25.

Themelis, N.J. (2007). Thermal treatment review, Waste Management World, 37.

USEPA (1999). Reuse of CERCLA Landfill and Containment Sites. Office of Emergency and Remedial Response, Document No. EPA 540-F-99-015.

Valujeva, K., Burlakovs, J., Grinfelde, I., Pilecka, J., Jani, Y., \& Hogland, W. (2018). Phytoremediation as tool for prevention of contaminant flow to hydrological systems. Research for Rural Development, 1, $188-194$. DOI: $10.22616 / \mathrm{rrd}$.24.2018.029.

Wong, C.T., Leung, M.K., Wong, M.K., \& Tang, W.C. (2013). Afteruse development of former landfill sites in Hong Kong, J. Rock Mech. Geotech. Eng., 5(6), 443-451. DOI: 10.1016/j.jrmge.2013.10.001. 